\section{Analysis of the degree of implementation of Health Academy Program in a Brazilian midsize town}

\author{
Análise do grau de implementação do Programa \\ Academia da Saúde em uma cidade brasileira \\ de porte médio
}

Flavio Renata Barros da Guarda 1 Renata Cecília Barbosa Carneiro 1 Rafaela Niels da Silva 1 Flávia Cristina Morone Pinto 1 Mathias Roberto Loch 2 Alex Antônio Florindo 3

doi: 10.1590/0102-311X00075020

\begin{abstract}
In 2011, the Brazilian Minister for Health created the Health Academy Program (Programa Academia da Saúde) as a strategy to promote health and healthy lifestyles. However, the official standards do not seem to be clear enough to support the implementation program in the towns. The aim of this study was to analyse the degree of Health Academy Program implementation in a Brazilian midsize town Vitória de Santo Antão, Pernambuco State, in 2018. This is an evaluative study that carry out a normative approach, considering the dimensions of structure and process related to work process. The research is divided into: (1) elaboration of the theoretical model of evaluation, through the validation of the logical model; (2) verification of the level of implementation, through an interview with workers and managers. The cutoff scores for classification of implementation levels were: (1) incipient: $>0<$ 33.3\%; (2) intermediate: $>33.3<66.6 \%$; (3) advanced: $>66.6 \%$. The level of implementation was considered intermediate (37.54\%). The score of the structure was higher (54.76\%) than the process (26.06\%). The low level of Health Academy Program implementation, especially related to the multi-professional articulation and the difficult connection with other sectors or social actors, shows the necessity of reorganization of the actions.
\end{abstract}

Health Evaluation; Primary Health Care; Exercise; Unified Health System

\author{
Correspondence \\ R. C. B. Carneiro \\ Rua da Alegria 1079, Limoeiro, PE 55700-000, Brasil. \\ rehcarneiro212@gmail.com \\ 1 Universidade Federal de Pernambuco, Recife, Brasil. \\ 2 Universidade Estadual de Londrina, Londrina, Brasil. \\ 3 Universidade de São Paulo, São Paulo, Brasil.
}




\section{Background}

The organization of the Brazilian Unified National Health System (SUS) has been outstanding in the search for the articulation between epidemiological, political, administrative specialties and the social context at the local degree, to the planning of actions and services in a network of health care, coordinated by the Family Health Strategy (FHS) 1.

These networks of health care presupposes a panoramic view of the necessities from health users, in order to meet their demands by a holistic vision, considering the complexity of the health problems and the demanding access to different actions and services. It also considers the needs for the political integration and intersectoral actions, in order to act more effectively on conditioning factors and determinants of the health-disease process 2 .

Demographic and epidemiological transition processes and changes in the population's lifestyle have reinforced the importance of comprehensive care and primary health care's (PHC) role as the organizer of care networks, especially in view of the advance of chronic non-communicable diseases. Although they are responsible for a large number of deaths, hospital admissions and the increase in the costs of public health systems ${ }^{3}$ have modifiable risk factors, whose population exposure can be reduced by policies and programs aimed to promote health and risk behavior prevention 4 .

Among the actions that have driven in the elaboration of guidelines aimed at health promotion and prevention of risk behaviors in the SUS, it was highlighted the innovation to investigate and follow-up the exposure of the population to risk factors for the chronic diseases 5 and the incentive to adopt an active lifestyle as a tool for health promotion and disease prevention, and its inclusion in the National Plan to Combat Chronic Non-communicable Diseases and in National Primary Care policies 6.

The health promotion was officially incorporated into the Brazilian health agenda in 2006, by the public policy published specifically for this purpose 7. In this scenario, in 2011 the creation of the Health Academy Program (Programa Academia da Saúde), aimed to contribute to health promotion through the construction of public spaces with infrastructure and qualified professionals for the orientation of physical activity, recreation and healthy lifestyles 5,8 .

The Health Academy Program was redefined in 2013, when the concept of care-production was incorporated and the physical activities were removed from the general objective, expanding the specific goals 6 . Nowadays, the Health Academy Program aims to contribute to health promotion through the creation of public spaces with suitable infrastructure and professionals qualified to develop the activities planned 9 . However, evidence show that the objectives are overwhelming, goals unattainable, and the guidelines are not clear enough to support implementation processes in the cities 6 .

The implementation assessment of intervention shows how operationally adequate it is to its guidelines and norms 10. This type of evaluation (also called normative evaluation) takes as reference the Donabedian triad 11,12, composed by structure, process and outcomes. The structure includes human resources, equipment and other relatively stable elements that are intended to offer the service. The process is directly linked to the performance of the care activities developed in the context of the intervention. Outcomes are related to the products of the activities and the changes in the health status of individuals and population 11,12 .

This evaluation is supported by the premise based on the strong relationship between the criteria and norms chosen, the real effects of the program or intervention 13 and suitability to evaluate complex interventions such as the Health Academy Program 14.

In this sense, the evaluation of the Health Academy Program implementation clarifies interventions, regarding the validity of its content and the nuances that can provide mismatch between its normative framework, planning, and execution of the actions 10 .

Conducting studies to analyse the degree of the Health Academy Program implementation will contribute to increase the field of knowledge about the evaluation of programs and policies aimed at Health Promotion and Physical Activity for the following reasons: (a) the Health Academy Program have strategic importance to the scope of health policies in Brazil; (b) this program requires a great amount of public health resources for execution; (c) to clarify the weaknesses of the implementation process of this type of program, contributing to the (re)orientation of the actions. 
As an example, a successful experiment can be cited: The Health Academy Program implemented from the success in the City Academy Program 15, which was initially carried out in Recife, Pernambuco in 2002 and showed effectiveness to improve the quality of life related to health 16 and increased the population degrees of physical activity in this city 17.

On the other hand, although these two programs aim to broaden the scope of health promotion actions, especially in primary care, they have different structures and work processes, which can impact on the achievement of the expected results. In addition, the degree of compliance with the guidelines established for the new program, the availability of resources and the organization of activities to meet the goal of contributing to health promotion, especially at the local degree, have not yet been verified.

In this context, the purpose of this study was to analyze the degree of implementation of the Health Academy Program in a Brazilian midsize town.

\section{Methodology}

This is an evaluative study with normative approach, considering the dimensions of structure and work process of the Health Academy Program in a Brazilian midsize town. The rationale of the evaluation of the implementation degree is the existence of a strong relationship between criteria and established standards and the effects of the program or the intervention 11,12,18.

The study was performed in Vitória de Santo Antão, located in the Northeast of Brazil, in the Pernambuco State, $48 \mathrm{~km}$ from Recife (the State capital). This town is considered the ninth most populous among the 185 towns of the state, with approximately 136,706 residents. The health network consists of 41 health family strategy units, 1 psychosocial support center, 26 specialized outpatient clinics, 5 family health strategy support teams and 4 small hospitals (Brazilian Health Informatics Department. http://tabnet.datasus.gov.br/cgi/tabcgi.exe?cnes/cnv/estabpe.def, accessed on 30/Aug/2020). The Human Development Index is considered medium (0.640), Gross Domestic Product per capita is BRL 23,647.17 (8th in the state and 1,653th in Brazil). The average monthly salary is BRL 1,812.60, which corresponds to the 20th position in the state and to 2,309th placement among the 5,570 Brazilian municipalities. The Gini Index is 0.54 (practically equal to state and national averages).

Vitória de Santo Antão is characterized by the prevalence of diseases of the circulatory system, hypertension and diabetes (Brazilian Health Informatics Department. http://tabnet.datasus.gov.br/ cgi/deftohtm.exe?sih/cnv/nrpe.def, accessed on 13/Dec/2017). In this context, the municipal health department implemented in 2013 two spots (called poles) of Health Academy Program, in the urban perimeter of the city, in order to expand the scope of health promotion and physical activity in the context of the FHS 5,8. Two physical education professionals work in each pole, offering exercises, walking and health education activities for approximately 80 persons per day. These poles support two health care units which are responsible for approximately 3,000 people each one.

The reasons to choose this town were: (a) epidemiological profile; (b) population size (more than 100,000 of the residents); (c) Health Academy Program implemented for more than 3 years, and; (d) to be located inside of a remote area of the state.

This study was divided into two stages: (1) elaboration of the theoretical model of evaluation, and; (2) evaluation of the degree of the Health Academy Program implementation through interviews using key-informants.

\section{Stage 1}

The theoretical model of the Health Academy Program evaluation was composed of the logical model and the matrices of assessment of the structure and work process 19.

The validation process of the logical model applied to Vitória de Santo Antão took as reference the model developed to the Health Academy Program evaluation in another town in Pernambuco (Figure 1), with similar characteristics ${ }^{6}$. This model was performed according to the review of the literature and the official Health Academy Program standards and guidelines. 
Figure 1

Logic model of the Health Academy Program.

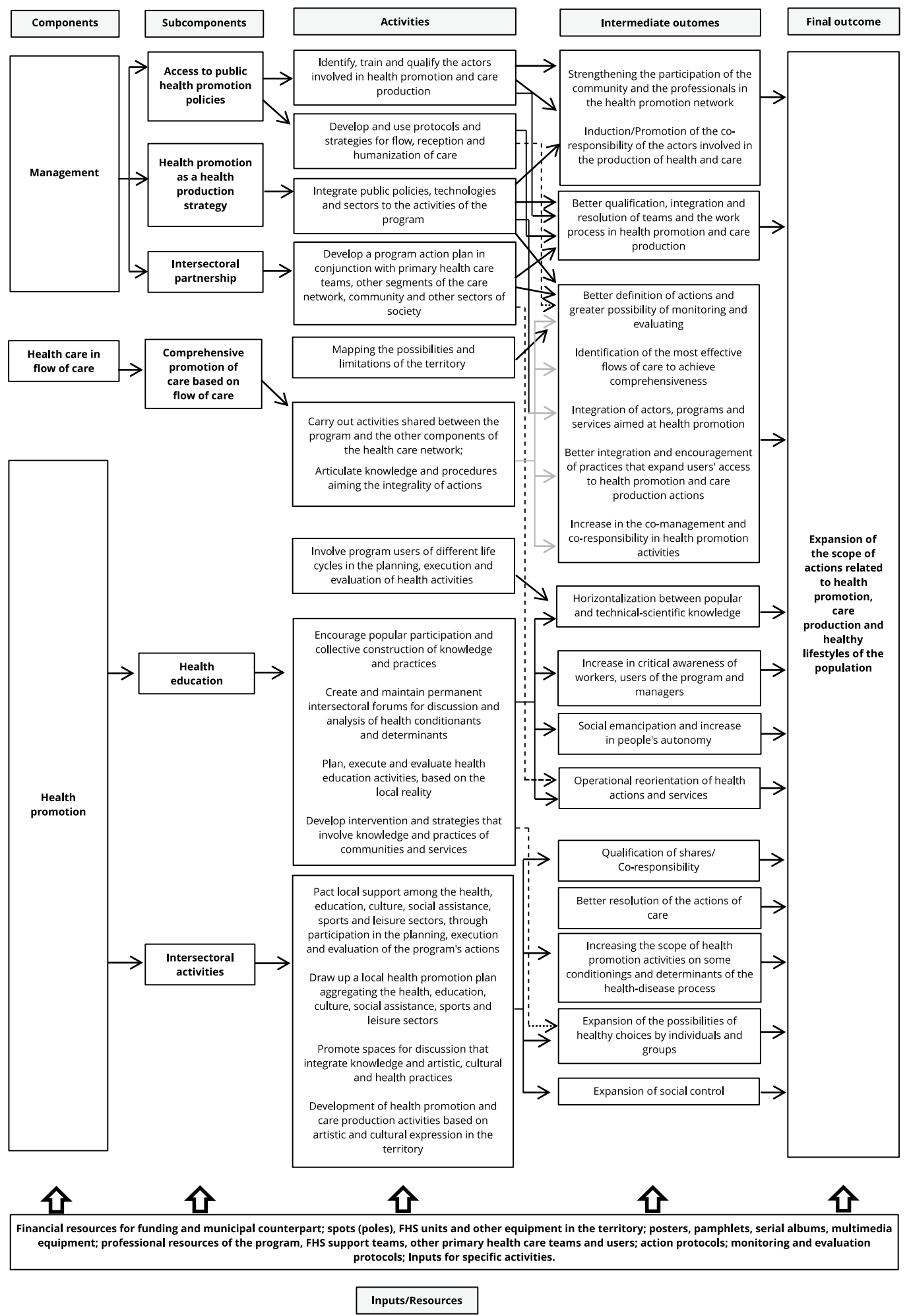

(continues) 
Figure 1 (continued)

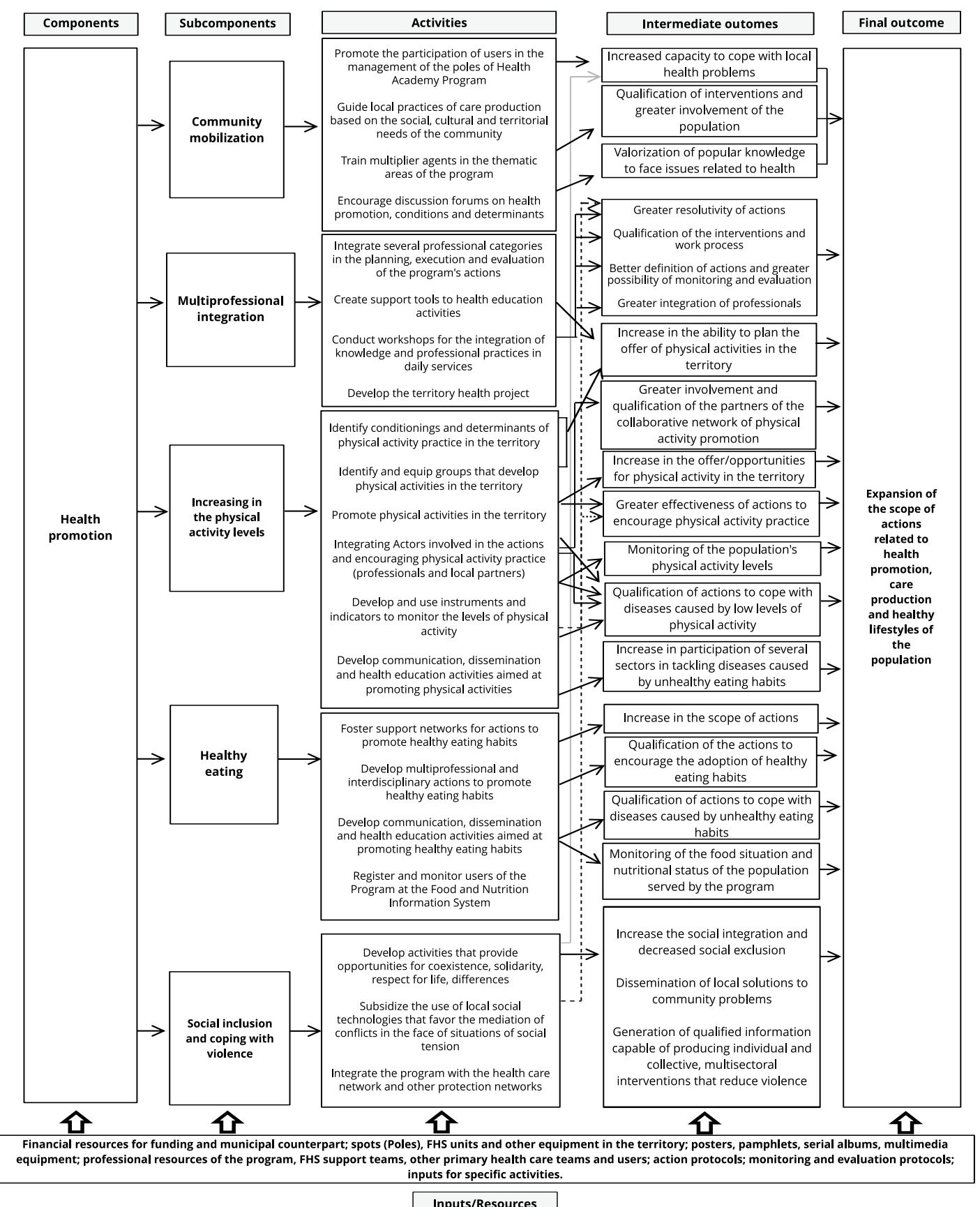

FHS: Family Health Strategy.

Source: Silva et al. 6. 
The logical model was validated by managers of the primary care districts and health promotion in the town and by the physical education professionals who work at the Health Academy Program's Vitória de Santo Antão (key-informants). They were selected because they carry out management and/or execution of program activities. The informants were guidance on how to analyze the relevance of the components related to official standards of Health Academy Program and to test the model consistency 20 . No changes to the model were required by the key-informants.

The relevance analysis verified if the components were aligned with the specifics objectives of the Health Academy Program and if they attended the exigencies of the actions of the Health Academy Program's Vitória de Santo Antão. To the consistency test, the key-informants analyzed if the connection between inputs and actions of the Health Academy Program produced the expected results for this intervention 20 .

In the validation process of the logical model, there was a consensus among key-informants about the adequacy and relevance of the components and about the results of the consistency test. In this sense, the program managers and workers considered that the model includes all the structural and procedural attributes necessary for the implementation, monitoring and evaluation of the Health Academy Program in the town.

From the logical model validated were elaborated the indicators and the inputs assessment matrices (structure) and the activities to be developed (process). These matrices are the tools that allow describing and quantifying whether the Health Academy Program is being implemented as planned 19,20. This study is restricted to analyse only the Health Academy Program structure and process. Because of this, we did not elaborate matrices for the verification of the impact of this intervention.

The structure and process matrices were based on topics: (i) Assessment criteria; (ii) Indicators; (iii) Evaluation standards; (iv) Scores for each indicator; (v) The value of each observation.

The consensus conference technique was used in the construction of the matrices, by the expert panel. The specialists (4) were health professionals, with expertise (Master degree and $\mathrm{PhD}$ ) in primary care and evaluation of physical activity programs. During the evaluation session, the experts were asked to check: (i) if the criteria were consistent with the official program (Health Academy Program) documents (guidelines) and related to the components of the logical model; (ii) if the indicators proposed for the matrices were empirically associated with the criteria and allowed to measure the the Health Academy Program actions and execution; (iii) if the proposed verification standards represented appropriate values to analyse the degree of the Health Academy Program implementation.

Regarding the judgment matrices, these were elaborated considering the components of the logical model and were composed by 32 indicators for structure and 40 indicators for work process. During the validation process, the expert panel required only two rounds of matrix appraisal to establish a consensus on the appropriateness of its criteria, indicators and verification standards.

\section{Stage 2}

This stage consisted of the elaboration of the questionnaires for the verification of the degree of implantation from the consensual evaluation of the matrices by the experts, in order to verify how much of the structure and the work process predicted for the program (Health Academy Program) were present in the routine of that intervention.

The questionnaires were applied in person by the researcher to all professionals (key-informants of the first stage of this study) involved in the management and execution of the program's actions in the municipality (six managers and four physical education professionals responsible for implementing the Health Academy Program actions in the town), from November 2017 to January 2018.

The degree of the Health Academy Program implementation was obtained from the completion of the Matrix of Indicators and Judgment, taking as reference the answers of the questionnaires. In the cases of discrepancy among the answers, the observations that could be verified through verification sources (meeting minutes, protocols and printed documents and photographs) as well as the presentation of materials and/or inputs were considered. Furthermore, the researchers performed the systematic observation of four sessions of Health Academy Program activities in different weeks and shifts.

The score established to measure the implementation degree of each indicator was calculated considering a rule of three, by dividing the number of indicators in each matrix (32 of structure and 
40 of process) by 100 . In this sense, the observed value can be represented by the number zero, by the maximum score for each indicator or by a fraction of that score in case of partial compliance with the verification standard.

For the final calculation of the degree of implantation, the items referring to the structure received weight four, and those of process, weight six. The respective division of weights occurred in view of the importance that each one has in order to promote the offer of the actions of the program, considering that having the structure for the proper development of the activities is very important, but does not necessarily imply the provision of good quality, if the work process is not directed towards the fulfilment of the objectives of the program 21,22.

Based on the score obtained in each criterion established in the matrix, the degree of the Health Academy Program implantation was defined from the following cut-off points, distributed in tertiles 23 : (1) incipient: > 0 and <33.3\%; (2) intermediate: $>33.3$ and < 66.6\%; (3) advanced: $>66.6 \%$.

\section{Results}

Women over 40 years-old are the main public of Health Academy Program in Vitória de Santo Antão, according to the systematic observation and official records of the program. This intervention develops activities in two places (poles) located in the east and west region of the town, from Monday to Friday, in the morning and afternoon shifts. Two physical education professionals at each pole develop daily guided exercise and walking sections, in addition to non-regular health education activities with a focus on encouraging the adoption of more active and healthy lifestyles, but with low participation and support from health professionals from the two family health units that are supported by the program.

The degree of the Health Academy Program implementation in Vitória de Santo Antão, was classified as intermediate (37.54\%), and the structure dimension obtained a higher score (54.76\%) than the work process $(26.06 \%)$.

\section{Assessment of the structure}

Among the structure indicators with the best scores were: the existence of a Program action plan focused on health promotion through physical activity, registration of the actors involved in these actions, such as nurses, care workers and professionals of physical education. An agreement was also made with the social assistance sector of the town.

On the other hand, the lack of program monitoring instruments of the assess the population's physical activity degrees, as well as the lack of instruments to identify the determinants and conditioning factors of physical activity practice in the population and for planning of social inclusion actions obtained low scores in the evaluation (Table 1).

\section{Assessment of the process}

Among the indicators with the highest degree of implementation were: professionals who developed activities in partnership with the community in the last month, professionals who used the action plan for the development of actions, performing at least 150 minutes of physical activity for the population and healthy eating activities once a week.

Indicators with a low degree of implementation include non-implementation of program monitoring actions, lack of articulation with other social actors, non-participation of users in program meetings, and absence of social inclusion activities (Table 2). 
Table 1

Matrix of Indicators and Judgment to the structure components of Heath Academy Program. Vitória de Santo Antão, Pernambuco State, Brazil, 2018.

\begin{tabular}{|c|c|c|c|c|}
\hline Assessment criterion & Indicators & Standards & $\begin{array}{l}\text { Scores for each } \\
\text { indicator }\end{array}$ & $\begin{array}{c}\text { Observed } \\
\text { values }\end{array}$ \\
\hline Management actions & $\begin{array}{l}\text { Existence of formal instruments for monitoring the } \\
\text { program's actions }\end{array}$ & To be present & Yes $=3.13$ & 0.00 \\
\hline $\begin{array}{l}\text { Health promotion actions in the } \\
\text { context of primary health care }\end{array}$ & $\begin{array}{l}\text { Existence of protocols for welcoming and } \\
\text { humanizing care in the program's actions }\end{array}$ & $\begin{array}{l}\text { Existence of at } \\
\text { least } 1 \text { protocol } \\
\text { for welcoming the } \\
\text { program }\end{array}$ & Yes $=3.13$ & 3.13 \\
\hline \multirow[t]{2}{*}{ Intersectoral actions } & Existence of an action plan to the program & To be present & Yes $=3.13$ & 3.13 \\
\hline & $\begin{array}{l}\text { Existence of forums or meetings with other health } \\
\text { network programs and other social actors }\end{array}$ & $\begin{array}{l}\text { Existence of at } \\
\text { least } 1 \text { forum } \\
\text { or semiannual } \\
\quad \text { meeting }\end{array}$ & Yes $=3.13$ & 3.13 \\
\hline \multirow[t]{2}{*}{$\begin{array}{l}\text { Production of comprehensive } \\
\text { care based on care lines }\end{array}$} & $\begin{array}{l}\text { Existence of a protocol for diagnosing the } \\
\text { possibilities of intervention in the territory }\end{array}$ & To be present & Yes $=3.13$ & 0.00 \\
\hline & $\begin{array}{l}\text { Existence of planning care articulated with other } \\
\text { actors, actions and health services aimed at } \\
\text { comprehensive }\end{array}$ & $\begin{array}{l}\text { Existence of at least } \\
1 \text { document (plan } \\
\text { or similar) since } \\
\text { the program was } \\
\text { created }\end{array}$ & Yes $=3.13$ & 3.13 \\
\hline Health education actions & Existence of support tools for health education & $\begin{array}{l}\text { Existence of at } \\
\text { least } 1 \text { tool since } \\
\text { the program was } \\
\text { created }\end{array}$ & Yes $=3.13$ & 3.13 \\
\hline Community mobilization & $\begin{array}{l}\text { Existence of the program management support } \\
\text { group formed by members of the local community }\end{array}$ & To be present & Yes $=3.13$ & 0.00 \\
\hline \multirow[t]{2}{*}{ Multiprofessional integration } & $\begin{array}{l}\text { Existence of a local plan that agrees with health } \\
\text { promotion actions with the health, education, } \\
\text { culture, social assistance, sports and leisure sectors }\end{array}$ & $\begin{array}{l}\text { Integration with at } \\
\text { least } 4 \text { sectors }\end{array}$ & $\begin{array}{l}\geq 4 \text { sectors }=3.13 \\
3 \text { sectors }=2.34 \\
2 \text { sectors }=1.56 \\
>2 \text { sectors }=0\end{array}$ & 2.34 \\
\hline & $\begin{array}{l}\text { Existence of protocols with definition of activities } \\
\text { and responsibilities for the development of } \\
\text { integration actions between the different } \\
\text { professional categories that work in the program }\end{array}$ & To be present & Yes $=3.13$ & 0.00 \\
\hline \multirow[t]{4}{*}{$\begin{array}{l}\text { Increasing of the physical } \\
\text { activity levels of the population }\end{array}$} & $\begin{array}{c}\text { Existence of a physical activities plan for the territory } \\
\text { covered by the Heath Academy Program }\end{array}$ & To be present & Yes $=3.13$ & 3.13 \\
\hline & $\begin{array}{l}\text { Existence of instruments to assess the levels of } \\
\text { physical activity in the population }\end{array}$ & To be present & Yes $=3.13$ & 0.00 \\
\hline & $\begin{array}{l}\text { Existence of instruments to identify conditions and } \\
\text { determinants of physical activity in the population }\end{array}$ & To be present & Yes $=3.13$ & 0.00 \\
\hline & $\begin{array}{l}\text { Existence of an instrument to monitor the frequency } \\
\text { of physical activity practices in the program }\end{array}$ & To be present & Yes = 3.13 & 3.13 \\
\hline \multirow[t]{2}{*}{$\begin{array}{l}\text { Promotion of healthy eating } \\
\text { habits }\end{array}$} & $\begin{array}{c}\text { Existence of an action plan to promote healthy } \\
\text { eating habits }\end{array}$ & To be present & Yes $=3.13$ & 3.13 \\
\hline & $\begin{array}{l}\text { Existence of support networks for the promotion of } \\
\text { healthy eating habits; }\end{array}$ & To be present & Yes $=3.13$ & 3.13 \\
\hline $\begin{array}{l}\text { Social inclusion and confronting } \\
\text { violence actions }\end{array}$ & $\begin{array}{c}\text { Existence of planning for social inclusion actions and } \\
\text { confronting violence; }\end{array}$ & To be present & Yes $=3.13$ & 0.00 \\
\hline
\end{tabular}

(continues) 
Table 1 (continued)

\begin{tabular}{|c|c|c|c|c|}
\hline Assessment criterion & Indicators & Standards & $\begin{array}{l}\text { Scores for each } \\
\text { indicator }\end{array}$ & $\begin{array}{l}\text { Observed } \\
\text { values }\end{array}$ \\
\hline \multirow[t]{7}{*}{ Human resources } & $\begin{array}{c}\text { Presence of at least one professional working } 40 \\
\text { hours a week or two working } 20 \text { hours each in the } \\
\text { program }\end{array}$ & To be present & Yes $=3.13$ & 3.13 \\
\hline & $\begin{array}{l}\text { \% of program professionals registered formally } \\
\text { linked to Brazilian Unified National Health System }\end{array}$ & $100 \%$ & $\begin{array}{c}100 \%=3.13 \\
50 \text { to } 75 \%=2.08 \\
0 \% \text { to } 49 \%=0\end{array}$ & 3.13 \\
\hline & $\begin{array}{l}\% \text { of primary health care professionals working in } \\
\text { the program }\end{array}$ & $80 \%$ & $\begin{array}{c}80 \%=3.13 \\
79 \text { to } 50 \%=2,08 \\
<50 \%=0,0\end{array}$ & 3.13 \\
\hline & $\begin{array}{l}\text { Existence of a doctor, nurse, dentist, social worker, } \\
\text { nutritionist, physiotherapist, occupational therapist, } \\
\text { psychologist, physical education professional, } \\
\text { veterinarian, speech therapist, pharmacist, } \\
\text { acupuncturist, health worker, music therapist, } \\
\text { arterapist and social educator working in the } \\
\text { program }\end{array}$ & $\begin{array}{c}\text { At least } 1 \\
\text { professional } \\
\text { working at Heath } \\
\text { Academy Program }\end{array}$ & $\begin{array}{c}<5=3.13 \\
5<3=2.34 \\
3<1=1.56 \\
>1=0\end{array}$ & 2.34 \\
\hline & $\begin{array}{l}\text { Presence of at least one professional who performs } \\
\text { physical activity in the program }\end{array}$ & To be present & Yes $=3.13$ & 3.13 \\
\hline & $\begin{array}{l}\text { Presence of at least one professional who performs } \\
\text { healthy eating actions }\end{array}$ & To be present & Yes $=3.13$ & 3.13 \\
\hline & $\begin{array}{l}\text { Presence of at least one professional at the Heath } \\
\text { Academy Program spots in both shifts (morning and } \\
\text { afternoon) }\end{array}$ & To be present & Yes $=3.13$ & 3.13 \\
\hline \multirow{6}{*}{$\begin{array}{l}\text { Necessary and adequate } \\
\text { resources for the development } \\
\text { of the program's activities }\end{array}$} & Existence of a meeting room for the program & To be present & Yes $=3.13$ & \\
\hline & Existence of consumable materials & To be present & Yes $=3.13$ & 0.00 \\
\hline & $\begin{array}{l}\text { Existence of necessary material for the development } \\
\text { of intersectoral actions, health education and } \\
\text { community mobilization }\end{array}$ & To be present & Yes $=3.13$ & 0.00 \\
\hline & $\begin{array}{l}\text { Existence of necessary material for the development } \\
\text { of physical activities }\end{array}$ & To be present & Yes $=3.13$ & 0.00 \\
\hline & $\begin{array}{l}\text { Existence of necessary material for the development } \\
\text { of healthy eating actions }\end{array}$ & To be present & Yes $=3.13$ & 0.00 \\
\hline & $\begin{array}{l}\text { Existence of necessary material for the development } \\
\text { of actions for social inclusion and confronting } \\
\text { violence }\end{array}$ & To be present & Yes $=3.13$ & 0.00 \\
\hline \multirow[t]{2}{*}{ Register of procedures } & $\begin{array}{l}\text { Existence of registration forms and frequency of } \\
\text { users at the centers }\end{array}$ & To be present & Yes $=3.13$ & 3.13 \\
\hline & $\begin{array}{c}\text { Existence of the Citizen's Electronic Health Record } \\
\text { (e-SUS-AB PEC) at the Heath Academy Program } \\
\text { spots }\end{array}$ & To be present & To be present & 0.00 \\
\hline Total for structure & & & & 54.76 \\
\hline
\end{tabular}




\section{Table 2}

Matrix of Indicators and Judgment to the process components of Heath Academy Program. Vitória de Santo Antão, Pernambuco State, Brazil, 2018.

\begin{tabular}{|c|c|c|c|c|}
\hline Assessment criterion & Indicators & Standards & Scores for each indicator & Observed values \\
\hline \multirow[t]{12}{*}{ Management actions } & $\%$ of professionals who are aware of & $100 \%$ & $100 \%=2.44$ & 1.22 \\
\hline & the program's rules & & 76 to $99 \%=1.83$ & \\
\hline & & & 50 to $75 \%=1.22$ & \\
\hline & & & 0 to $49 \%=0.00$ & \\
\hline & $\begin{array}{l}\text { Updating the registration of } \\
\text { professionals in the human } \\
\text { resources information system }\end{array}$ & To be present & Yes $=2.44$ & 0.00 \\
\hline & $\begin{array}{l}\text { Carrying out continuing and in- } \\
\text { service training activities on health } \\
\text { promotion or on the program's } \\
\text { actions at least once in the last year }\end{array}$ & To be present & Yes $=2.44$ & 0.00 \\
\hline & $\%$ of program professionals who & $100 \%$ & $100 \%=2.44$ & 0.00 \\
\hline & participated in continuing education & & 76 to $99 \%=1.83$ & \\
\hline & and/or in-service activities in the last & & 50 to $75 \%=1.22$ & \\
\hline & year & & 0 to $49 \%=0$ & \\
\hline & $\begin{array}{l}\text { Participation of professionals from } \\
\text { the health care network in ongoing } \\
\text { and in-service training activities } \\
\text { on health promotion or program } \\
\text { actions in the last year }\end{array}$ & To be present & Yes $=2.44$ & 0.00 \\
\hline & Monthly monitoring of the program & Yes or No & Yes $=2.44$ & 0.00 \\
\hline \multirow{8}{*}{$\begin{array}{l}\text { Health promotion actions } \\
\text { in the context of primary } \\
\text { health care }\end{array}$} & $\%$ of professionals who developed & $100 \%$ & $100 \%=2.44$ & 2.44 \\
\hline & activities in partnership with the & & 76 to $99 \%=1.83$ & \\
\hline & community in the last month & & 50 to $75 \%=1.22$ & \\
\hline & & & 0 to $49 \%=0.00$ & \\
\hline & $\%$ of professionals who developed & $100 \%$ & $100 \%=2.44$ & 0.00 \\
\hline & activities in partnership with other & & 76 to $99 \%=1.83$ & \\
\hline & points of the health care network in & & 50 to $75 \%=1.22$ & \\
\hline & the last month & & 0 to $49 \%=0.00$ & \\
\hline
\end{tabular}

(continues) 
Table 2 (continued)

\begin{tabular}{|c|c|c|c|c|}
\hline Assessment criterion & Indicators & Standards & Scores for each indicator & Observed values \\
\hline \multirow[t]{9}{*}{ Intersectoral actions } & $\%$ of professionals who use the & $100 \%$ & $100 \%=2.44$ & 2.44 \\
\hline & program's action plan to develop & & 76 to $99 \%=1.83$ & \\
\hline & actions & & 50 to $75 \%=1.22$ & \\
\hline & & & 0 to $49 \%=0.00$ & \\
\hline & $\begin{array}{l}\text { Conducting of one program activity } \\
\text { involving partners from strategic } \\
\text { sectors for health promotion in the } \\
\text { last year }\end{array}$ & $\begin{array}{l}\text { Carrying out at least } 1 \\
\text { activity }\end{array}$ & Yes $=2.44$ & 0.00 \\
\hline & $\begin{array}{l}\text { Holding a forum or meeting with } \\
\text { other health care network programs } \\
\text { in the last } 6 \text { months }\end{array}$ & Conducting at least 1 forum & Yes $=2.44$ & 0.00 \\
\hline & $\begin{array}{l}\text { Holding a forum or meeting } \\
\text { with strategic sectors for health } \\
\text { promotion in the last year }\end{array}$ & Conducting at least 1 forum & Yes $=2.44$ & 0.00 \\
\hline & $\begin{array}{l}\text { Articulation with the health, } \\
\text { education, culture, social assistance, } \\
\text { sports and leisure sectors for the } \\
\text { development of health promotion } \\
\text { actions in the last year }\end{array}$ & $\begin{array}{l}\text { Articulation with at least } 4 \\
\text { sectors }\end{array}$ & $\begin{array}{c}\leq 4 \text { sectors }=2.44 \\
3 \text { sectors }=1 \\
2 \text { sectors }=1.22 \\
<2 \text { sectors }=0.00\end{array}$ & 0.00 \\
\hline & $\begin{array}{l}\text { Performing the diagnosis of the } \\
\text { possibilities of the program's } \\
\text { performance in the territory in the } \\
\text { last year }\end{array}$ & $\begin{array}{l}\text { At least } 1 \text { diagnosis in the } \\
\text { last year }\end{array}$ & Yes $=2.44$ & 0.00 \\
\hline \multirow[t]{6}{*}{$\begin{array}{l}\text { Production of } \\
\text { comprehensive care based } \\
\text { on care lines }\end{array}$} & $\begin{array}{c}\% \text { of professionals who use flows or } \\
\text { protocols of activities shared with } \\
\text { other actors, actions and health } \\
\text { services aiming at comprehensive } \\
\text { care }\end{array}$ & $100 \%$ & $\begin{array}{c}100 \%=2.44 \\
76 \text { to } 99 \%=1.83 \\
50 \text { to } 75 \%=1.22 \\
0 \text { to } 49 \%=0.00\end{array}$ & 0.00 \\
\hline & $\%$ of professionals in the program & $100 \%$ & $100 \%=2.44$ & 0.00 \\
\hline & who used protocols to welcoming & & 76 to $99 \%=1.83$ & \\
\hline & and humanize care at least once in & & 50 to $75 \%=1.22$ & \\
\hline & the last month & & 0 to $49 \%=0.00$ & \\
\hline & $\begin{array}{l}\text { Carrying out care orientation } \\
\text { activities in the territory }\end{array}$ & At least 1 weekly activity & Yes $=2.44$ & \\
\hline \multirow[t]{2}{*}{ Health education actions } & $\begin{array}{l}\text { Carrying out health education } \\
\text { activities in the territory covered by } \\
\text { the Health Academy Program }\end{array}$ & $\begin{array}{l}\text { At least } 1 \text { activity per } \\
\text { month. }\end{array}$ & Yes $=2.44$ & 0.00 \\
\hline & $\begin{array}{c}\text { Carrying out health education } \\
\text { activities that use popular knowledge } \\
\text { and practices }\end{array}$ & $\begin{array}{l}\text { At least } 1 \text { activity in the last } \\
3 \text { months }\end{array}$ & Yes $=2.44$ & 0.00 \\
\hline \multirow[t]{3}{*}{ Community mobilization } & $\begin{array}{l}\text { Conducting community mobilization } \\
\text { activities }\end{array}$ & $\begin{array}{l}\text { At least } 1 \text { activity in the last } \\
6 \text { months }\end{array}$ & Yes $=2.44$ & 0.00 \\
\hline & $\begin{array}{l}\text { Carrying out of meetings of the } \\
\text { community group support for } \\
\text { program management }\end{array}$ & To be present & Yes $=2.44$ & 0.00 \\
\hline & $\begin{array}{c}\text { User participation in program } \\
\text { meetings at least once in the last } 6 \\
\text { months }\end{array}$ & Holding at least 1 meeting & Yes $=2.44$ & 0.00 \\
\hline
\end{tabular}

(continues) 
Table 2 (continued)

\section{Assessment criterion}

Multiprofessional integration

Increasing of the physical activity levels of the population

Promotion of healthy eating habits

\section{Indicators}

Standards

Scores for each indicator

(with the sectors of education,

culture, social assistance, sports and leisure) in the last year

Carrying out activities aimed at the population, involving partners from other sectors in the last 6 months

$\%$ of program professionals who use support tools in the field of health education

Conducting a workshop to integrate knowledge and professional

practices in the daily life of services in the last 6 months

$\%$ of professionals who developed activities in partnership with primary healthcare teams in the last month

Participation of different professional categories in the development of the program's actions

Promoting of at least 150 minutes of physical activity per week in the territory

$\%$ of professionals who used the physical activity plan in the last semester

Conducting surveys to identify the levels of physical activity of the population in the last year Conducting surveys to identify the determinants and conditioning

factors of physical activity practice in the population in the last year $\%$ of professionals who use instruments to monitor the frequency of physical activity practices in the program

Carrying out healthy eating activities in the territory at least once a week $\%$ of professionals who used the action plan to promote healthy eating habits in the last semester Development of action to articulate support networks for the promotion
Yes $=2.44$

0.00 last year

At least 1 meeting in the

At least 1 action

Yes $=2.44$

0.00

$100 \%$

$100 \%=2.44$

76 to $99 \%=0.33$

50 to $75 \%=0.22$

0 to $49 \%=0.00$

At least 1 workshop

Yes $=2.44$

$100 \%$

$100 \%=2.44$

76 to $99 \%=0.33$

50 to $75 \%=0.22$

0 to $49 \%=0.00$

At least 5 categories

4 to 5 categories $=2.44$

2 to 3 categories $=0.22$

1 category $=0.00$

At least 150 minutes a week

$\geq 150$ minutes $=2.44$

$<150>120$ minutes $=0.33$

$<120>90$ minutes $=0.22$

$<90$ minutes $=0.00$

$80 \%$

$80 \%=2.44$

79 to $50 \%=0.81$

$<50 \%=0.00$

To be present

Yes $=2.44$

To be present

Yes $=2.44$

0.00

$80 \%$

$80 \%=2.44$

79 to $50 \%=0.81$

$<50 \%=0.00$

Yes $=2.44$

$80 \%=2.44$

2.44

79 to $50 \%=0.81$

$<50 \%=0.00$

To be present

Yes $=2.44$ the last year

\section{of healthy eating habits in}

(continues) 
Table 2 (continued)

\begin{tabular}{|c|c|c|c|c|}
\hline Assessment criterion & Indicators & Standards & Scores for each indicator & Observed values \\
\hline $\begin{array}{l}\text { Social inclusion and } \\
\text { confronting violence actions }\end{array}$ & $\begin{array}{l}\text { Conducting activities to social } \\
\text { inclusion and confronting violence at } \\
\text { least once in the last } 6 \text { months }\end{array}$ & To be present & Yes $=2.44$ & 0.00 \\
\hline Human resources & $\begin{array}{c}\% \text { of professionals in the territory } \\
\text { who develop activities in the Health } \\
\text { Academy Program }\end{array}$ & $80 \%$ & $\begin{array}{c}80 \%=2.44 \\
79 \text { to } 50 \%=0.81 \\
<50 \%=0.00\end{array}$ & 0.00 \\
\hline Register of procedures & $\begin{array}{l}\% \text { of professionals who register the } \\
\text { procedures at the Electronic Records } \\
\text { of the Citizen }\end{array}$ & $100 \%$ & $\begin{array}{c}100 \%=2.44 \\
76 \text { to } 99 \%=0.33 \\
50 \text { to } 75 \%=0.22 \\
0 \text { to } 49 \%=0.00\end{array}$ & 0.00 \\
\hline & $\begin{array}{l}\text { Registration of information related } \\
\text { to the actions of the program in at } \\
\text { least } 80 \% \text { of the Electronic Records } \\
\text { of the Citizen }\end{array}$ & $80 \%$ & $\begin{array}{c}80 \%=2.44 \\
79 \text { to } 50 \%=0.81 \\
<50 \%=0.00\end{array}$ & 0.00 \\
\hline & $\begin{array}{c}\% \text { of professionals who register } \\
\text { monthly activities in the production } \\
\text { of the program }\end{array}$ & $100 \%$ & $\begin{array}{c}100 \%=2.44 \\
76 \text { to } 99 \%=0.33 \\
50 \text { to } 75 \%=0.22 \\
0 \text { to } 49 \%=0.00\end{array}$ & 2.44 \\
\hline Total to process & & & & 26.06 \\
\hline
\end{tabular}

\section{Discussion}

The proposed theoretical model for the Health Academy Program assessment in Vitória de Santo Antão showed to be adequate and applicable to the reality of the town, which is reflected in the consensus presented in the validation of the logical model between the key-informants and the judgment matrices by the experts. This model showed that the program is partially implemented, presenting positive elements such as the existence (structure) and use (process) of a program action plan focused on health promotion through physical activity and the offer of more than 150 minutes per week of these activities. On the other hand, the absence of instruments for the diagnosis and monitoring of activities, as well as the absence of social control and inclusion actions and the lack of articulation of the program with other actions and services in the town reflect the fragility of the implementation of this intervention in the local context.

The implementation assessment of public health interventions is characterized as an important instrument for decision making and advancement in the scientific area ${ }^{10}$. In this study, the highest degree of implementation was found on the structure dimension, compared with the process dimension. Possibly it is related to the fact of the presence of structure elements does not necessarily imply the satisfactory execution of the activities or a proportion that is equivalent to the resources 22 .

The complexity of the overall Health Academy Program objectives (contributing to health promotion and care production), as well as a wide range of specific objectives, principles and guidelines for its implementation can make the process of the Health Academy Program implementation difficult. This difficulty has already been highlighted in a survey on Health Academy Program availability in Recife 6 and is reflected on large number of indicators for evaluation of the structure $(n=32)$ and process $(n=40)$, fundamental for the verification of the degree of implantation in the town.

In the implementation of the structure dimension, it was observed that some of the indicators described as critical in the town studied were also reported in a study on the Health Academy Program in other cities 24 . The absence of action monitoring instruments has been pointed out in other studies when evaluating the Health Academy Program 25. This study also points to the lack of action protocols and instruments for assessing the degree of physical activity of the population, which was also verified as a critical indicator of the program. In contrast, the existence of a program action plan focused 
on health promotion through physical activity, shows the direction of the Health Academy Program towards the accomplishment of its tenth specific objective, which aims to increase the physical activity degrees of the population 8 . In this sense, the satisfactory operationalization of this criterion points to the strengthening of the actions foreseen in the Strategic Action Plan for Tackling Chronic NonCommunicable Diseases in Brazil 5. In its turn, satisfactory performance on only one criterion may denote fragmentation of care and little effectiveness of actions 25 .

The evaluation of the process dimension helped in the understanding that the activities developed in the program are adequate and can contribute to achieve the expected results 11,12. Among negative points, we highlight the absence of interventions in partnership with the community and other points of the Health Care Network, and the non-performance of social inclusion activities and coping with violence. These actions show a scenario of insufficient multiprofessional and intersectoral articulation of the program and are incipient in relation to the guidelines of the Health Academy Program, which point to the need for constant intra and intersectoral approach, both in the context of the health care network, as well as in the integration with health actions with sectors such as education, culture, sport and leisure 8 .

The lack of articulation with other health services in the municipal network, as well as the little intersectoral integration observed in the municipality studied was also observed in other Brazilian cities 6 . This scenario can impact on the comprehensiveness of care, because the articulation with the other components of the health care network is characterized as a fundamental element for establishing priorities, adapting actions to the epidemiological profile of the community and building effective care lines 15,16,17,26.

Regarding the criteria of increasing the levels of physical activity and the promotion of healthy eating habits, these also resemble the results of other work process studies in the Health Academy Program 8,27. However, these two criteria are described in studies as the most developed activities by the Health Academy Program in Brazil 27. In this sense, the lack of identification of the physical activity levels of the population, as well as the conditioning factors and determinants of this practice, point to a difficulty to monitor these actions and verify the fulfillment of this specific objective of the program.

As a limitation of this study, it is highlighted the impossibility of verifying what factors of the political-normative, technical-managerial and organizational contexts can influence the degree of the Health Academy Program implementation in towns. On the other hand, the research involved all stakeholders interested in the evaluation (specialists, managers and workers) and used different strategies to develop, validate and apply instruments that allowed understanding the program theory and the relevance and applicability of an evaluation model 11,12,20, which can be reproduced to analyze other community health promotion and physical activity programs.

The results of this research allowed identifying the best and worst indicators of the program, showing evidence to support decision-making processes, both in management and in the implementation of interventions, focused on promoting more active and healthy lifestyles by supporting evidence-informed policymaking.

The Health Academy Program of Vitória de Santo Antão is an intermediate degree of implantation, with a general score above the incipient degree, and larger structure dimension than the process score. These results point for reorientation of actions, especially regarding the development of planning instruments, monitoring of activities, compliance with multiprofessional actions within the health sector and the development of integration activities with other actors and institutions. In addition, the Health Academy Program actions are fragmented, with predominance of educational interventions aimed at promoting healthy eating habits, encouraging and offering physical activities, which represent only two of the 14 specific objectives of the program.

The degree of implementation situated near to the limit between the incipient and intermediate degrees can compromise the quality of services provided to the population, raising questions about the effectiveness of these intervention in view of its financial costs, both for the federal manager (the Brazilian Ministry of Health) and the investment made for the construction of the spots and costing of the Health Academy Program, as well as for the municipality itself, which provides resources from its own budget to complement the total costs (direct and indirect) of the program as a form of counterpart to the federal investment. 


\section{Contributors}

F. R. B. Guarda and R. C. B. Carneiro contributed to data collection, writing and review of the article. R. N. Silva, M. R. Loch and A. A. Florindo contributed by writing and reviewing the article. F. C. M. Pinto contributed to the review and approval of the article.

\section{Additional informations}

ORCID: Flavio Renata Barros da Guarda (00000002-9214-7784); Renata Cecília Barbosa Carneiro (0000-0003-4351-723X); Rafaela Niels da Silva (0000-0001-8065-0780); Flávia Cristina Morone Pinto (000-0001-9196-7687); Mathias Roberto Loch (0000-0002-2680-4686); Alex Antônio Florindo (0000-0002-4429-0826).

\section{References}

1. Macinko J, Matthew JH. Brazil's Family Health Strategy - delivering community-based primary care in a Universal Health System. N Engl J Med 2015; 372:2177-81.

2. Paim J, Travassos C, Almeida C, Bahia L, Macinko J. The Brazilian health system: history, advances, and challenges. Lancet 2011; 377:1778-97.

3. Schmidt MI, Duncan BB, Silva GA, Menezes AM, Monteiro CA, Barreto SM, et al. Chronic non-communicable diseases in Brazil: burden and current challenges. Lancet 2011; 377:1949-61.

4. Orrow G, Kinmonth AL, Sanderson S, Sutton S. Effectiveness of physical activity promotion based in primary care: systematic review and meta-analysis of randomised controlled trials. BMJ 2012; 344:e1389.

5. Malta DC, Oliveira TP, Santos MAS, Andrade SSCA, Silva MMA. Progress with the strategic action plan for tackling chronic non-communicable diseases in Brazil, 2011-2015. Epidemiol Serv Saúde 2016; 25:373-90.

6. Silva RN, Guarda FRB, Hallal PC, Martelli PJL. Avaliabilidade do Programa Academia da Saúde no Município do Recife, Pernambuco, Brasil. Cad Saúde Pública 2017; 33:e00159415.

7. Malta DC, Silva MMA, Albuquerque GM, Lima CM, Cavalcante T, Jaime PC, et al. A implementação das prioridades da Política Nacional de Promoção da Saúde, um balanço, 2006 a 2014. Ciênc Saúde Colet 2014; 19:4301-12.

8. Florindo AA, Reis RS, Farias JJC, Siqueira FV, Nakamura PM, Hallal PC. Description of health promotion actions in Brazilian cities that received funds to develop "Academia da Saúde” program. Rev Bras Cineantropom Desempenho Hum 2016; 18:483-92.

9. Hallal PC. Physical activity and health in Brazil: research, surveillance and policies. Cad Saúde Pública 2014; 30:2487-9.

10. Leviton LC, Khan LK, Rog D, Dawkins N, Cotton D. Evaluability assessment to improve public health policies, programs, and practices. Annu Rev Public Health 2010; 31:213-33.
11. Donabedian A. The quality of care: how can it be assessed? JAMA 1988; 260:1743-8.

12. Donabedian A. Evaluating the quality of medical care. 1966. Milbank Q 2005; 83:691-729.

13. Rossi PH, Freeman HE. Evaluation: a sistematic approach. Los Angeles: Sage; 1985.

14. Hartz ZMA, Vieira da Silva LM. Avaliação em saúde: dos modelos teóricos à prática na avaliação de programas e sistemas de saúde. 4th Ed. Rio de Janeiro: Editora Fiocruz/Salvador: EdUFBA; 2014.

15. Parra DC, Hoehner CM, Hallal PC, Reis RS, Simões EJ, Malta DC, et al. Scaling up of physical activity interventions in Brazil: how partnerships and research evidence contributed to policy action. Glob Health Promot 2013; 20:512.

16. Soares JS, Simões EJ, Ramos LR, Pratt M, Brownson RC. Cross-sectional associations of health-related quality of life measures with selected factors: a population-based sample in Recife, Brazil. J Phys Act Health 2010; 7 Suppl 2:S229-41.

17. Simões EJ, Hallal P, Pratt M, Ramos L, Munk M, Damascena W, et al. Effects of a community-based, professionally supervised intervention on physical activity degrees among residents of Recife, Brazil. J Public Health 2009; 99:68-75.

18. Leahy MJ, Thielsen VA, Millington MJ, Austin B, Fleming A. Quality assurance and program evaluation: terms, models, and applications. Journal of Rehabilitation Administration 2009; 33:69-82.

19. Centers for Disease Control and Prevention. Monitoring and evaluation of capacity building program improvement. Field guide. v. 1. Atlanta: Centers for Disease Control and Prevention; 2003.

20. Leeuw FL. Reconstructing program theories: methods available and problems to be solved. American Journal of Evaluation 2003; 24:5-20.

21. Samico I, Felisberto E, Figueiró AC, Frias PG. Avaliação em saúde: bases conceituais e operacionais. Rio de Janeiro: MedBook; 2010. 
22. Brouselle A, Champagne F, Contrandiopoulos AP, Hartz ZM. Avaliação: conceitos e métodos. Rio de Janeiro: Editora Fiocruz; 2011.

23. Vieira da Silva LM, Hartz ZMA, Chaves SCM, Silva GAP. Metodologia para análise da implantação de processos relacionados à descentralização da atenção à saúde no Brasil. In: Hartz ZMA, Vieira da Silva LM. Avaliação em saúde: dos modelos teóricos à prática na avaliação de programas e sistemas de saúde. 4th Ed. Rio de Janeiro: Editora Fiocruz/Salvador: EdUFBA; 2014. p. 207-53.

24. Guarda FRB, Silva RN, Feitosa WMN, Santos Neto PM, Araújo Júnior JLAC. Caracterização das equipes do Programa Academia da Saúde e do seu processo de trabalho. Rev Bras Ativ Fís Saúde 2015; 20:638-49.
25. Guarda FRB, Silva RN, Feitosa WMN, Farias JM, Santos Neto PM, Araújo Júnior JLAC. Selfperception of the objective, object and work products of Physical Education Professionals belonging to the Academia da Saúde. Rev Bras Ativ Fís Saúde 2016; 21:400-9.

26. Hallal PC, Reis RS, Parra DC, Hoehner CM, Brownson R, Simões EJ. Association between perceived environmental attributes and physical activity among adults in Recife, Brazil. J Phys Act Health 2010; 7 Suppl 2:S213-22.

27. Sá GBAR, Dornelles GC, Cruz KG, Amorim RC, Andrade SSC, Oliveira TP, et al. The Health Academy Program as a strategy to promote health and healthy lifestyles: the national implementation scenario. Ciênc Saúde Colet 2016; 21:1849-60. 


\section{Resumo}

Em 2011, o Ministério da Saúde criou o Programa Academia da Saúde como estratégia para promover a saúde e estilos de vida saudáveis. Entretanto, as normas oficiais não parecem ser suficientemente claras para apoiar a implementação do programa nas cidades. O estudo teve como objetivo analisar o grau de implementação do Programa Academia da Saúde em uma cidade brasileira de porte médio, Vitória de Santo Antão, Pernambuco, em 2018. É um estudo avaliativo com abordagem normativa, considerando as dimensões de estrutura e processo relacionadas ao processo de trabalho. O estudo é divido em dois passos: (1) a elaboração de um modelo teórico de avaliação, através da validação do modelo lógico e (2) a verificação do nível de implementação através de entrevistas com os profissionais e gestores. Os pontos de corte para a classificação dos níveis de implementação foram: (1) incipiente: $>0<33,3 \%$; (2) intermediário: > 33,3 < 66,6\%; (3) avançado > 66, 6\%. O grau de implantação foi considerado intermediário $(37,54 \%)$. A pontuação da estrutura foi mais alta $(54,76 \%)$ que a do processo (26,06\%). O nível baixo de implementação do Programa Academia da Saúde, principalmente relacionado a problemas de articulação multi-profissional e à dificuldade de articulação com os outros setores e atores da sociedade, mostra a necessidade de reorganização das ações.

Avaliação em Saúde; Atenção Primária à Saúde; Exercício Físico; Sistema Único de Saúde

\section{Resumen}

El ministro brasileño de salud creó en 2011 el Programa Academia de la Salud (Programa Academia da Saúde) como estrategia para promover la salud y estilos de vida saludables. Sin embargo, los estándares oficiales no parecen estar lo suficientemente claros para apoyar la implementación del programa en las ciudades. El objetivo de este estudio fue analizar el grado de implementación del Programa Academia de la Salud en un pueblo de tamaño medio en Brasil (Vitória de Santo Antão, Pernambuco) en 2018. Es un estudio evaluativo, con un enfoque normativo, que considera las dimensiones de la estructura y proceso relacionado con el sistema laboral. La investigación está dividida en dos pasos: (1) elaboración del modelo teórico de evaluación, a través de la validación del modelo lógico; (2) verificación del nivel de implementación, mediante una entrevista con trabajadores y gestores. Las puntuaciones de corte para la clasificación de implementación por niveles fueron: (1) incipiente: > $0 y<33,3 \%$; (2) intermedios: $>$ 33,3 y < 66,6\%; (3) avanzados: > 66,6\%. El nivel de implementación fue considerado intermedio (37,54\%). La puntuación de la estructura fue mayor (54,76\%) que el proceso (26,06\%). El bajo nivel de implementación del Programa Academia de la Salud, especialmente relacionado con la coordinación multiprofesional, y la difícil conexión con otros sectores o actores de la sociedad, muestra la necesidad de una reorganización de las acciones.

Evaluación en Salud; Atención Primaria de Salud; Ejercício Físico; Sistema Único de Salud

Submitted on 13/Apr/2020

Final version resubmitted on 30/Aug/2020

Approved on 04/Sep/2020 